\title{
The Effectiveness of Guided Inquiry Learning Models for Students' Scientific Performances and Critical Skills
}

\section{Efektivitas Guided Inquiry Learning Model Untuk Meningkatkan Scientific Attitude Dan Skill Critical Thinking Peserta Didik}

\author{
Triyo Supriyatno', Dirga Ayu Lestari2, Ulfa Utami ${ }^{3}$ \\ 1,2,3Universitas Islam Negeri Maulana Malik Ibrahim Malang, Indonesia \\ 1triyo@pai.uin-malang.ac.id 2dirales25@gmail.com ${ }^{3}$ ulfahutami@bio.uin-malang.ac.id
}

\begin{abstract}
This study aims to analyze learning activities using guided inquiry learning models in improving scientific attitudes and students' critical thinking skills and the effectiveness of guidedinquiry learning models in improving scientific attitudes and students' critical thinking skills inscience learning. This research was a quasi-experimental research with purposive samplingtechnique. Subjects in this study were 51 students of class V MIN 1 Serang. Data collection useddocumentation, questionnaires, observations and tests. Data were collected from the pretest andposttest of the students' scientific attitude and critical thinking as well as documentation and observation of guided inquiry learning activities in the control class and the experimental class.The type of data analysis used t-Test and effect size cohen's test with the help of the statisticalpackage for the social sciences (SPSS) program version 23.0. The results showed that the guidedinquiry model learning activities were better than conventional models namely. So, there is theeffectiveness of guided inquiry learning models in improving scientific attitudes and criticalthinking skills of students on science learning in class.

Keywords: Guided Inquiry Learning Model; Students' Scientific Attitudes; Student Critical Thinking Skills; Natural Science.
\end{abstract}

\begin{abstract}
Abstrak. Penelitian ini bertujuan untuk menganalisis kegiatan pembelajaran menggunakan model pembelajaran inkuiri terbimbing dalam meningkatkan sikap ilmiah dan keterampilan berpikir kritis siswa dan efektivitas model pembelajaran inkuiri terbimbing dalam meningkatkan sikap ilmiah dan keterampilan berpikir kritis siswa dalam pembelajaran sains. Penelitian ini adalah penelitian eksperimen semu dengan teknik purposive sampling. Subjek dalam penelitian ini adalah 51 siswa kelas V MIN 1 Serang. Pengumpulan data menggunakan dokumentasi, kuesioner, observasi dan tes. Data dikumpulkan dari pretest dan posttest dari sikap ilmiah dan pemikiran kritis siswa serta dokumentasi dan observasi kegiatan pembelajaran inkuiri terbimbing di kelas kontrol dan kelas eksperimen. Jenis analisis data menggunakan uji t-Test dan efek ukuran cohen dengan bantuan paket statistik untuk program ilmu sosial (SPSS) versi 23.0. Hasil penelitian menunjukkan bahwa kegiatan pembelajaran model inkuiri terbimbing lebih baik daripada model konvensional yaitu. Jadi, ada efektifitas model pembelajaran inkuiri terbimbing dalam meningkatkan sikap ilmiah dan keterampilan berpikir kritis siswa pada pembelajaran sains di kelas.
\end{abstract}

Kata Kunci: Model Pembelajaran Inkuiri Terbimbing; Sikap Ilmiah Peserta didik; Keterampilan Berpikir Kritis Peserta didik; Pembelajaran IPA

Received : 17-05-2020

Approved : 01-07-2020

Revised : 30-06-2020

Published : 13-07-2020 
Copyright ( Madrasah Jurnal Pendidikan dan Pembelajaran Dasar. All Right Reserved.

This is an open access article under the CC BY-NC-ND license

(http://creativecommons.org/licenses/by-nc-nd/4.0/).

Correspondence Address: triyo@pai.uin-malang.ac.id

\section{A. PENDAHULUAN}

Proses pembelajaran yang berkualitas dapat dicapai dengan memperhatikan standar mutu proses dan hasil belajar peserta didik. Dalam riset Ridwan (2014) menyebutkan tentang skill peserta didik dalam memahami konten dan konteks serta skill komunikasi. Riset Sularso (dkk., 2017) menyebutkan pentingnya skill dan kecakapan peserta didik dalam memahami problematika IPTEK dan lingkungan global. Riset Sudarisman (2012) menyebutkan perlu adanya revolusi institusi Pendidikan dalam vis a vis kemajuan teknologi dan ilmu pengetahuan. Peran intitusi dalam menyiapkan output pendidikannya adalah menyiapkan peserta didik yang memiliki skill individu dan skill critical thinking vis a vis persaingan global. Kajian institusi National Research Council (2011) menyebutkan ilmu pengetahuan alam sebagai proses kajian dalam konsep penemuan yang berhubungan dengan studi alam sekitas. Maknanya, pembelajaran IPA di sekolah atau madrasah merupakan proses penemuan yang berbasis alam semesta secara sistematis berdasarkan prosedur ilmiah. Sehingga peserta didik dalam pembelajaran IPA dapat memiliki knowledge dan skill berupa skill critical thinking dan skill of understanding of concept (Sudarisman, 2012; Handayani, dkk., 2017; Puspita, dkk., 2017; Saidaturrahmi, dkk., 2019).

Pembelajaran di era 4.0 adalah pembelajaran yang berbasis pada unjuk kerja siswa dan perang guru menjadi fasilitator dan tutor sebaya dapat diimplementasikan sehingga peserta didik dapat menjadi pebelajar mandiri dan produktif. Pembelajaran ini cenderung memberikan kepada peserta didik untuk dapat melakukan riset dan menemukan solusi dari problem sains yang dipelajarinya. Dalam riset Lestari (2015) menyebutkan proses pembelajaran IPA didominasi oleh skill afektif berupa rasa ingin tahu, meneliti, sikap logis, dan fleksibel yang juga merupakan sikap ilmiah peserta didik. Dalam riset Ennis dan Falahuddin menyebutkan pembelajaran aktif peserta didik dapat menghasilkan outcome berupa skill critical thinking dalam menyelesaikan masalah sains dan reflective thinking dalam sikap mengambil keputusan (dalam Irham, dkk., 2016). Outcome akhir dari pembelajaran IPA berupa skill critical thinking tingkat tinggi (C4C6) dalam wujudnya berupa rasional decision terhadap perilaku sehari-hari yang dilandasi keyakinan rasionalnya (Nur, 2008). Selain itu Nur (2008) menyebutkan knowledge, attitude, dan skill menjadi asas utama dalam proses pembelajaran, bukan penghafalan.

Fenomena pembelajaran saat ini, pendidik masih menerapkan pembelajaran yang berbasis pada teacher center, menafikan student center sehingga peserta didik kurang memiliki skill critical thinking yang sesuai dengan kaidah ilmiah sains. Pada akhirnya peserta didik kurang memiliki skill dalam eksperimen sains dan tidak mandiri dalam menyelesaikan problematika sains dalam kehidupan. Dampak dari pembelajaran berbasis teacher center akan menghasilkan outcome yang tidak mandiri pada peserta didik, ketidakmampuan peserta didik dalam pengembangan skill critical thinking dan keberanian dalam mencari tahu pengetahuannya serta mudah menyerah vis a vis problematika sains. Demikian juga pada akhirnya akan berdampak pada keyakinan diri pada peserta didik dalam menghadapi problematika kehidupan era 5.0. Fenomena 


\section{MADRASAH}

Jurnal Pendidikan dan Pembelajaran Dasar

p ISSN: 1979-5599 | e ISSN: 2502-194X

P a g e | 3

outcome belajar siswa berupa nilai mata pelajaran IPA mengalami penurunan drastis (berdasarkan hasil interview) yang didominasi oleh faktor skill pendidik dalam manajemen pembelajaran di kelas. Manajemen pembelajaran pendidik di kelas akan berdampak pada kualitas proses pembelajaran peserta didik dan juga akan mempengaruhi ouput hasil belajarnya.

Salah satu bentuk dalam manajemen pembelajaran pendidik adanya inquiry learning model di mana dalam kajian Ulva (2017) menyebutkan adanya pengaruh antara inquiry learning model yang diterapkan oleh pendidik di kelas terhadap attitude ilmiah peserta didik berupa sikap percaya diri, rasa ingin tahu, kerjasama, disiplin, jujur, peduli lingkungan, teliti, bertanggung jawab dan mengelola informasi, sedangkan pada indikator hati-hati mendapatkan kriteria baik dalam scientific attitude peserta didik. Riset Kuhlthau (2010) menyebutkan guided inquiry learning model dapat membantu peserta didik dalam pembelajaran aktif, dan kesadaran tentang pentingnya proses pembelajaran dalam memahami, dan menciptakan banyak ilmu pengetahuan, terutama akan menjadi scientific attitude peserta didik, serta membentuk skill critical thinking peserta didik yang dibentuk oleh peserta didik itu sendiri dan dapat berdampak dalam hidup keseharian peserta didik. Begitu pula riset Sutisna (2017: 27) menyebutkan penerapan guided inquiry learning model dapat membentuk dan membiasakan peserta didik melakukan critical thinking sampai pada higher critical thinking (C4-C6) peserta didik. Selain itu, juga menjelaskan perolehan suatu ilmu pengetahuan melalui penyelidikan dalam kegiatan guided inquiry learning model. Aktivitas penelitian dari pendidik kepada peserta didik melalui pertanyaan-pertanyaan yang ditindaklanjuti dengan mengembangkan data-data yang berdasarkan pertimbangan bukti data yang dimiliki. Dari sini dapat dikendalikan terhadap skill kemampuan belajar secara mandiri dan menemukan temuan pengetahuan yang dialaminya sendiri. Dari aktivitas pembelajaran ini, peserta didik melatih dirinya secara mandiri untuk mengonstruksi pengalamannya dalam membentuk pengetahuan sehingga memiliki rasa tanggung jawab dan skill critical thinking nya akan meningkat. Riset Prince (2006) menyebutkan understanding peserta didik dalam pembelajaran sains dan nilai akademik dapat meningkat dengan penerapan guided inquiry learning model. Model ini dapat juga menerapkan $5 \mathrm{M}$ dan peserta didik dapat melakukan percobaan serta menyimpulkan sendiri berdasarkan prosedur scientific.

Berasaskan konteks riset di atas, jika dilakukan analisa maka ada beberapa aspek yang menghambat dan mendukung pembelajaran IPA atau sains dengan penerapan scientific approach, begitu pula, pentingnya meningkatkan scientific attitude dan skill critical thinking dalam pembelajaran IPA atau sains di kelas. Fenomena ini dapat dilakukan untuk mencapai mutu pendidikan yang lebih baik. Tercapainya tujuan pendidikan yang ada dalam KI-2 dan KI-3 dalam pembelajaran IPA yaitu scientific attitude peserta didik dan skill critical thinking peserta didik menjadi penting dilakukan penelitian, dengan menerapkan guided inquiry learning model dalam pembelajaran IPA. Riset ini melihat penerapan pembelajaran dengan menggunakan guided inquiry learning model dalam meningkatkan scientific attitude dan skill critical thinking peserta didik dan menganalisa efektivitas guided inquiry learning model dalam meningkatkan scientific attitude dan skill critical thinking peserta didik pada pembelajaran IPA.

\section{B. METODE PENELITIAN}


Rancangan dalam riset ini mengunakan jenis kuantitatif, berjenis penelitian eksperimen kuasi (quasi experimental) (dalam Sukamdinata, Nana Syaodih, 2012: 59). Teknik pengambilan data mengunakan pretest dan posttest. Desain yang digunakan pada penelitian ini adalah nonequivalentkontrol-group pretest-posttest. Populasi dalam penelitian ini seluruh peserta didik kelas V. Sampel pada penelitian pada ini dalah kelas V A sebagai kelas eksperimen dan Kelas V C sebagai kelas kontrol dengan mengunakan teknik purposive sampling. Teknik pengumpulan data pada penelitian menggunakan beberapa teknik pengumpulan data diantaranya kuesioner/angket, observasi, tes dan dokumentasi. Instrumen penelitian mengunakan kuesioner, panduan observasi di kelas, dan butir soal uraian untuk mengukur keterampilan berpikir kritis peserta didik.

Pelaksanaan penelitian dilakukan dengan tiga tahap yakni pretest, pelaksanaan proses pembelajaran dan posttest. Teknik analisis data yang digunakan untuk menganalisis efektivitas sikap ilmiah dan keterampilan berpikir kritis, mengunakan uji normalitas menggunakan uji Kolmogorof-Smirnov, lalu uji homogenitas dan uji $t$ sebagai uji perbandingan. Sampel dibagi dua kelompok, ada kelompok control (kelas C) dan ada kelompok eksperimen (kelas A). Perlakuan kepada kedua kelompok ini berbeda sesuai dengan karakteristiknya. Kelas A diperlakukan dengan menggunakan inquiry learning model yang dalam prosesnya menerapkan langkah-langkah 6M di kelas, sedangkan kelas $\mathrm{C}$ diperlakukan dengan menggunakan classical convensional model. Kedua kelas diperlakukan sama dalam hal pretest dan posttest.

\section{HASIL DAN PEMBAHASAN}

\section{Penerapan Guided Inquiry Learning Model dalam Meningkatkan Scientific Attitude dan Skill Critical Thinking Peserta didik}

Proses pembelajaran di kelas A, pendidik menerapkan pembelajaran aktif yang berbasis pada peserta didik dan di kelas C, pendidik menerapkan pembelajaran pasif yang berbasis pada pendidik. Kondisi pembelajaran kedua kelompok berbeda dengan tujuan untuk melihat dan mengukur tentang ada atau tidaknya pengaruh model pembelajaran terhadap scientific attitude peserta didik dan skill critical thinking peserta didik. Dari penyebaran kuesioner ini untuk memperbandingkan hasil sebaran pada kedua kelas tersebut. Untuk data hasil kuesioner dapat dilihat pada lampiran. Angket ini digunakan untuk menganalisis respon peserta didik terhadap model pemeblajaran yang digunakan di kelas eksperimen dan kelas kontrol. Hal ini menunjuukkan seberapa besar ketertarikan atau motivasi belajar peserta didik dengan penggunaan model pembelajaran yang diberikan dapat dilihat pada tabel 1 .

Tabel C.1 Analisa kuesioner di kedua kelas

\begin{tabular}{lclc}
\hline Kelompok & Kategori Angket & F & Prosentase (\%) \\
\hline Eksperimen & Ya & 22 & 84,61 \\
& Tidak & 4 & 15,39 \\
& Total & 26 & 100,0 \\
\hline \multirow{2}{*}{ Kontrol } & Ya & 8 & 32 \\
& Tidak & 17 & 68 \\
& Total & 25 & 100,0 \\
\hline
\end{tabular}

Pada table C.1 di atas menyebutkan adanya responden sebanyak 22 orang $(84,61 \%)$ yang menunjukkan proses pembelajaran guided inqury learning model lebih disenangi dan nyaman oleh peserta didik daripada 4 orang (15,39\%) yang tidak 


\section{MADRASAH}

Jurnal Pendidikan dan Pembelajaran Dasar

p ISSN: 1979-5599 | e ISSN: 2502-194X

merespon terhadap proses pembelajaran guided inqury learning. Fenomena ini terjadi pada kelas A (eksperimen) dan bebrbeda dengan kelas kontrol yang merupakan kebalikan dari kelas A. Dapat dilihat bahwa respon positif ada pada kelas A daripada kelas C. Maka dapat dinyatakan bahwa pembelajaran guided inquiry learning model dapat berpengaruh dalam meningkatkan scientific attitude dan skill critical thinking peserta didik.

Riset di atas mendukung riset yang telah dilakukan oleh Oliveira (2010: 257) yang menyebutkan dan membuktikan adanya proses pembelajaran guided inquiry learning model dalam pengembangan intellectual potensial dan level of thinking peserta didik. Fenomena ini terbukti karena dalam proses pembelajaran, peserta didik dapat belajar secara langsung dan mengalami long term memory dalam menyerap pelajaran. Dan mendukung puka riset Newman (2004: 261) menyebutkan adanya pengaruh antara guided inquiry learning model dan science learning experience peserta didik serta learning motivation. Begitu pula riset Piaget (2010: 114) menyebutkan adanya pengaruh dalam thinking skill, active sensing, directly involved in habituation, dan exercises on problem solving, serta akan memahami learning how to learn. Fenomena di atas dapat terjadi karena guru dan peserta didik memiliki sikap ilmiah dan keterampilan berfikir kritis yang diwujudkan dalam kegiatan pembelajaran melalui model pembelajaran inkuiri terbimbing.

\section{Efektivitas Guided Inquiry Learning Model dalam Meningkatkan Scientific Attitude Peserta didik pada Pembelajaran}

Scientific attitude pada riset ini menggunakan 10 indikator scientific attitude yaitu Curiosity (Rasa Ingin Tahu), Honesty (Jujur), Through (Teliti), Be careful (Hati-Hati), Responsible (Bertanggung Jawab), Enviromental care (Peduli Lingkungan), Cooperation (Kerja Sama), Confidence (Percaya Diri), Discipline (Disiplin), Manage Information (Mengelola Informasi). Untuk menganalisis 10 indikator ini disebar pada kelas $\mathrm{C}$ dan kelas A yang masing-masing diperlakukan pada tatap muka pertama sampai ketiga. Rincian hasil penyebaran kuisioner dapat dilihat pada tabel 2 berikut.

Tabel C.2 Analisa Scientific Attitude pada Tatap Muka Ke-1 di Kelas C

\begin{tabular}{llccl}
\hline No & \multicolumn{1}{c}{$\begin{array}{c}\text { Indikator scientific } \\
\text { attitude }\end{array}$} & Jumlah Skor & $\begin{array}{c}\text { Prosentase Indikator } \\
\text { JS / JM x 10\% }\end{array}$ & Kategori \\
\hline 1. & $\begin{array}{l}\text { Curiosity (Rasa Ingin } \\
\text { Tahu) }\end{array}$ & 39 & 52 & Kurang \\
\hline 2. & Honesty (Jujur) & 41 & 53 & Kurang \\
\hline 3. & Thorough (Teliti) & 44 & 59 & Cukup \\
\hline 4. & Be careful (Hati-Hati) & 46 & 61 & Cukup \\
\hline 5. & $\begin{array}{l}\text { Responsible (Bertanggung } \\
\text { Jawab) }\end{array}$ & 43 & 57 & Cukup \\
\hline 6. & $\begin{array}{l}\text { Enviromental care (Peduli } \\
\text { Lingkungan) }\end{array}$ & 40 & 53 & Cukup \\
\hline 7. & Cooperation (Kerja Sama) & 41 & 55 & Cukup \\
\hline 8. & Confidence (Percaya Diri) & 45 & 60 & Cukup \\
\hline 9. & Discipline (Disiplin) & 52 & 56 & Kurang \\
\hline 10. & $\begin{array}{l}\text { Manage Information } \\
\text { (Mengelola Informasi) }\end{array}$ & 39 & 52 & \\
\hline
\end{tabular}


Pada table C. 2 di atas menyebutkan adanya 40\% dalam kategori kurang dan $60 \%$ dalam kategori cukup. Kategori kurang masih tampak pada indikator scientific attitude berupa Curiosity (Rasa Ingin Tahu), Honesty (Jujur), Enviromental care (Peduli Lingkungan), dan Manage Information (Mengelola Informasi). Keempat scientific attitude ini menjadi keyword dalam pembentukan scientific attitude lainnya. Fenomena ini dapat diketahui karena adanya pengaruh model pembelajaran classical conventional dalam tatap muka di kelas. Perubahan akan tampak jika kelas diperlakukan lagi seperti semula namun penambahan tatap muka ditambah sebagaimana ada pada tatap muka kedua seperti pada contoh table 3 .

Tabel C.3 Analisis Hasil Sikap Ilmiah Tatap Muka Ke-2 di Kelas Kontrol

\begin{tabular}{|c|c|c|c|c|}
\hline No & Indikator scientific attitude & Jumlah Skor & $\begin{array}{c}\begin{array}{c}\text { Prosentase } \\
\text { Indikator } \\
\text { JS / JM x 10\% }\end{array} \\
\end{array}$ & Kategori \\
\hline 1. & Curiosity (Rasa Ingin Tahu) & 40 & 53 & Kurang \\
\hline 2. & Honesty (Jujur) & 41 & 55 & Cukup \\
\hline 3. & Thorough (Teliti) & 46 & 61 & Cukup \\
\hline 4. & Be careful (Hati-Hati) & 45 & 60 & Cukup \\
\hline 5. & Responsible (Bertanggung Jawab) & 43 & 57 & Cukup \\
\hline 6. & $\begin{array}{lll}\text { Enviromental } & \text { care } & \text { (Peduli } \\
\text { Lingkungan) }\end{array}$ & 39 & 52 & Kurang \\
\hline 7. & Cooperation (Kerja Sama) & 41 & 55 & Cukup \\
\hline 8. & Confidence (Percaya Diri) & 45 & 60 & Cukup \\
\hline 9. & Discipline (Disiplin) & 44 & 59 & Cukup \\
\hline 10. & $\begin{array}{l}\text { Manage Information (Mengelola } \\
\text { Informasi) }\end{array}$ & 40 & 53 & Kurang \\
\hline
\end{tabular}

Pada table C.3 di atas jika dicermati maka ada perubahan yang signifikan pada scientific attitude berupa sikap honesty (jujur) menjadi kategori cukup. Selain itu, diketahui pula nilai rata-rata tiap indikator scientific attitude peserta didik yang diperoleh di kelas kontrol dengan menerapkan model pembelajaran klasikal konvensional dapat dilihat hasil prosentase indikator scientific attitude. Pada tatap muka kedua, prosentase indikator scientific attitude peserta didik di kelas C berkategori kurang untuk indikator rasa ingin tahu, peduli lingkungan dan mengelola informasi, sedangkan pada indikator jujur, teliti, hati-hati, bertanggung jawab, kerja sama, percaya diri dan disiplin pada kategori cukup. Fenomena ini menunjukkan scientific attitude peserta didik di kelas $\mathrm{C}$ belum mencapai maksimal atau dikatakan belum mencapai baik seperti pada tabel 4 .

Tabel C.4 Analisa Hasil Scientific attitude pada Tatap Muka Ke-3 di Kelas C.

\begin{tabular}{clccc}
\hline No & \multicolumn{1}{c}{$\begin{array}{c}\text { Indikator scientific } \\
\text { attitude }\end{array}$} & $\begin{array}{c}\text { Jumlah } \\
\text { Skor }\end{array}$ & $\begin{array}{c}\text { Prosentase Indikator } \\
\text { JS / JM x 10\% }\end{array}$ & Kategori \\
\hline 1. & $\begin{array}{l}\text { Curiosity (Rasa Ingin } \\
\text { Tahu) }\end{array}$ & 41 & 55 & Cukup \\
\hline 2. & Honesty (Jujur) & 41 & 55 & Cukup \\
\hline 3. & Thorough (Teliti) & 45 & 60 & Cukup \\
\hline 4. & Be careful (Hati-Hati) & 45 & 60 & Cukup \\
\hline
\end{tabular}




\section{MADRASAH}

Jurnal Pendidikan dan Pembelajaran Dasar

p ISSN: 1979-5599 | e ISSN: 2502-194X

\begin{tabular}{clccc}
\hline No & \multicolumn{1}{c}{$\begin{array}{c}\text { Indikator scientific } \\
\text { attitude }\end{array}$} & $\begin{array}{c}\text { Jumlah } \\
\text { Skor }\end{array}$ & $\begin{array}{c}\text { Prosentase Indikator } \\
\text { JS / JM x 10\% }\end{array}$ & Kategori \\
\hline 5. & $\begin{array}{l}\text { Responsible } \\
\text { (Bertanggung Jawab) }\end{array}$ & 43 & 57 & Cukup \\
\hline 6. & $\begin{array}{l}\text { Enviromental care } \\
\text { (Peduli Lingkungan) }\end{array}$ & 39 & 52 & Kurang \\
\hline 7. & $\begin{array}{l}\text { Cooperation (Kerja } \\
\text { Sama) }\end{array}$ & 42 & 56 & Cukup \\
\hline 8. & $\begin{array}{l}\text { Confidence (Percaya } \\
\text { Diri) }\end{array}$ & 45 & 60 & Cukup \\
\hline 9. & Discipline (Disiplin) & 45 & 60 & Cukup \\
\hline 10. & $\begin{array}{l}\text { Manage Information } \\
\text { (Mengelola Informasi) }\end{array}$ & 42 & 56 & Cukup \\
\hline
\end{tabular}

Pada table C.4 di atas menyebutkan nilai rata-rata pada indikator scientific attitude peserta didik yang diperoleh di kelas $C$ dengan menerapkan model pembelajaran klasikal konvensional dapat dilihat dari hasil propsentase indikator scientific attitude. Pada tatap muka ketiga, prosentase indikator sikap ilmiah peserta didik di kelas $\mathrm{C}$ ada 9 indikator scientific attitude berkategori cukup, namun indikator scientific attitude yang masih masuk kategori kurang yaitu peduli lingkungan. Fenomena menunjukkan bahwa sikap ilmiah peserta didik di kelas $C$ belum mencapai maksimal atau dapat dinyatakan belum baik sekalipun terdapat sedikit peningkatan scientific attitude pada setiap pembelajaran.

Berdasarkan pemaparan hasil scientific attitude dengan model konvesional di kelas kontrol di atas, maka dapat digambarkan perkembangan sikap ilmiah peserta didik dengan rekapitulasi sikap ilmiah dengan tabel 5 ini.

Tabel C.5 Analisa Scientific Attitude Peserta didik di Kelas C.

\begin{tabular}{|c|c|c|c|c|c|c|}
\hline \multirow[b]{2}{*}{ No } & \multirow[b]{2}{*}{$\begin{array}{c}\text { Indikator } \\
\text { Scientific Attitude }\end{array}$} & \multicolumn{3}{|c|}{ Proses Pembelajaran } & \multirow[b]{2}{*}{ Rata-Rata } & \multirow[b]{2}{*}{ Kategori } \\
\hline & & $\begin{array}{c}\text { Tatap } \\
\text { muka } 1\end{array}$ & $\begin{array}{c}\text { Tatap } \\
\text { muka } 2\end{array}$ & $\begin{array}{c}\text { Tatap } \\
\text { muka } 3\end{array}$ & & \\
\hline 1 & $\begin{array}{ll}\text { Curiosity } & \text { (Rasa } \\
\text { Ingin Tahu) }\end{array}$ & 52 & 53 & 55 & 53.333333 & Kurang \\
\hline 2 & Honesty (Jujur) & 53 & 55 & 55 & 54.333333 & Kurang \\
\hline 3 & Thorough (Teliti) & 59 & 61 & 60 & 60 & Cukup \\
\hline 4 & $\begin{array}{l}\text { Be careful (Hati- } \\
\text { Hati) }\end{array}$ & 61 & 60 & 60 & 60.333333 & Cukup \\
\hline 5 & $\begin{array}{l}\text { Responsible } \\
\text { (Bertanggung } \\
\text { Jawab) }\end{array}$ & 57 & 57 & 57 & 57 & Cukup \\
\hline 6 & $\begin{array}{l}\text { Enviromental care } \\
\text { (Peduli } \\
\text { Lingkungan) }\end{array}$ & 53 & 52 & 52 & 52.333333 & Kurang \\
\hline 7 & $\begin{array}{l}\text { Cooperation (Kerja } \\
\text { Sama) }\end{array}$ & 55 & 55 & 56 & 55.333333 & Cukup \\
\hline 8 & $\begin{array}{l}\text { Confidence } \\
\text { (Percaya Diri) }\end{array}$ & 60 & 60 & 60 & 60 & Cukup \\
\hline
\end{tabular}




\begin{tabular}{c|l|c|c|c|c|c}
\hline \multirow{2}{*}{ No } & \multicolumn{1}{|c|}{$\begin{array}{c}\text { Indikator } \\
\text { Scientific Attitude }\end{array}$} & $\begin{array}{c}\text { Tatap } \\
\text { muka 1 }\end{array}$ & $\begin{array}{c}\text { Tatap } \\
\text { muka 2 }\end{array}$ & $\begin{array}{c}\text { Tatap } \\
\text { muka 3 }\end{array}$ & \multirow{2}{*}{ Rata-Rata } & \multirow{2}{*}{ Kategori } \\
\hline 9 & $\begin{array}{l}\text { Discipline } \\
\text { (Disiplin) }\end{array}$ & 56 & 59 & 60 & 58.333333 & Cukup \\
\hline 10 & $\begin{array}{l}\text { Manage } \\
\text { Information } \\
\text { (Mengelola } \\
\text { Informasi) }\end{array}$ & 52 & 53 & 56 & 53.666667 & Kurang \\
\hline
\end{tabular}

Penjabaran perkembangan sikap ilmiah peserta didik di kelas control dapat dilihat dalam bentuk gambar seperti gambar C.1 ini.

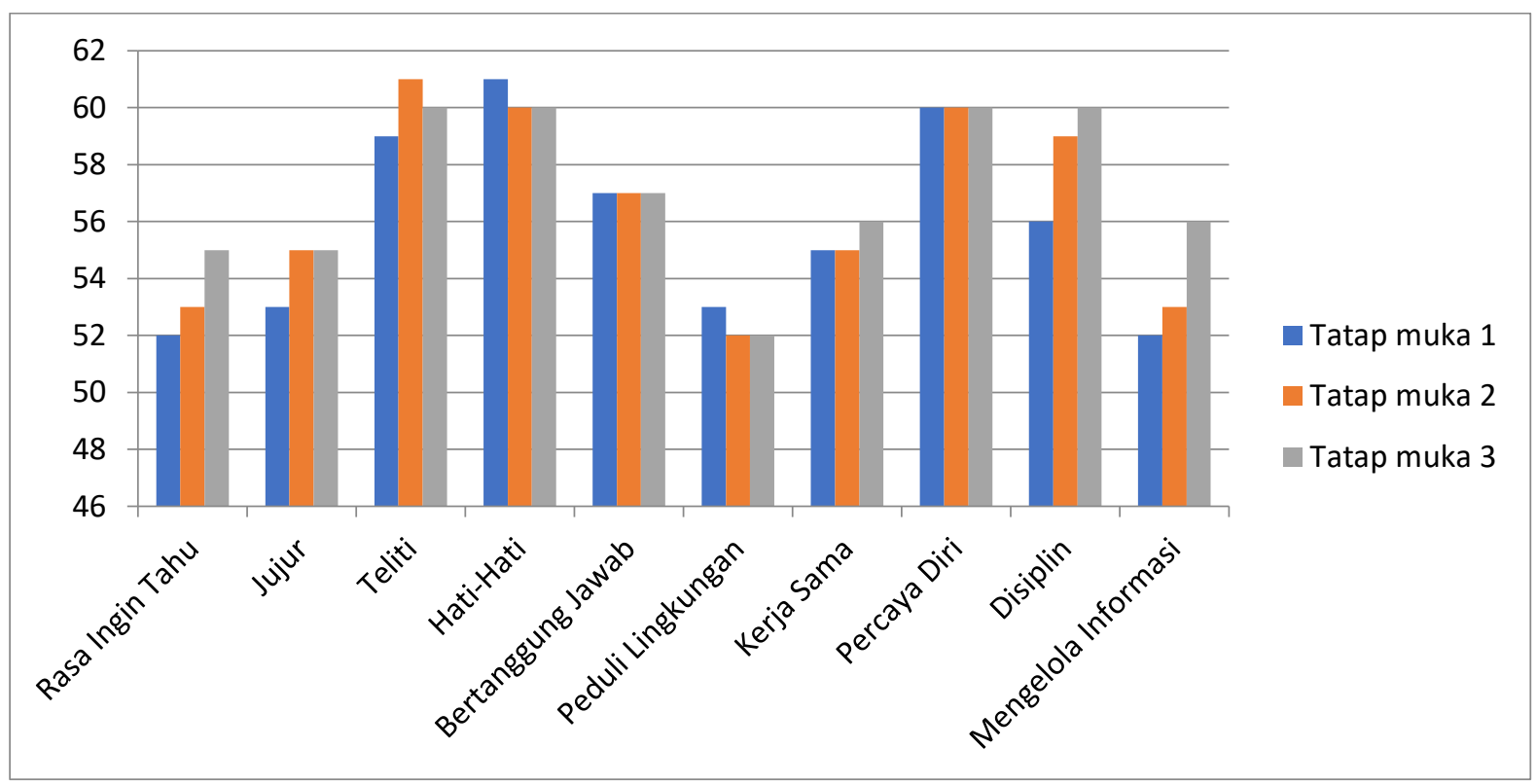

Gambar C.1

Analisa Perkembangan Scientific Attitude Peserta didik di Kelas C.

Pada gambar C.1 di atas menyebutkan scientific attitude peserta didik di kelas C mencakup 10 indikator belum nampak peningkatan yang signifikan. Sikap ilmiah peserta didik pada rekapitulasi menujukkan indikator scientific attitude berupa rasa ingin tahu, jujur, peduli lingkungan dan mengelola informasi berkategori kurang, sedangkan sikap ilmiah berupa sikap teliti, hati-hati, bertanggung jawab, kerja sama, percaya diri dan disiplin baru mencapai kategori cukup. Adapun perkembangan scientific attitude peserta didik dapat dilihat dari rekapitulasi sikap ilmiah dengan tabel 6 berikut.

Tabel C.6 Analisa Hasil Rekapitulasi Scientific Attitude Peserta didik di Kelas A

\begin{tabular}{|c|c|c|c|c|c|c|}
\hline \multirow[b]{2}{*}{ No } & \multirow[b]{2}{*}{$\begin{array}{c}\text { Indikator scientific } \\
\text { attitude }\end{array}$} & \multicolumn{3}{|c|}{ Proses Pembelajaran } & \multirow[b]{2}{*}{$\begin{array}{l}\text { Rata- } \\
\text { Rata }\end{array}$} & \multirow[b]{2}{*}{ Kategori } \\
\hline & & $\begin{array}{c}\text { Tatap } \\
\text { muka } 1\end{array}$ & $\begin{array}{c}\text { Tatap } \\
\text { muka } 2\end{array}$ & $\begin{array}{c}\text { Tatap } \\
\text { muka } 3\end{array}$ & & \\
\hline 1 & Rasa Ingin Tahu & 74 & 86 & 87 & 82.3 & Baik \\
\hline 2 & Jujur & 86 & 86 & 87 & 86.3 & Baik Sekali \\
\hline 3 & Teliti & 86 & 86 & 95 & 89 & Baik Sekali \\
\hline 4 & Hati-Hati & 86 & 88 & 90 & 88 & Baik Sekali \\
\hline
\end{tabular}




\section{MADRASAH}

Jurnal Pendidikan dan Pembelajaran Dasar

p ISSN: 1979-5599 | e ISSN: 2502-194X

Pag e | 9

\begin{tabular}{|c|c|c|c|c|c|c|}
\hline \multirow[b]{2}{*}{ No } & \multirow{2}{*}{$\begin{array}{c}\text { Indikator scientific } \\
\text { attitude }\end{array}$} & \multicolumn{3}{|c|}{ Proses Pembelajaran } & \multirow{2}{*}{$\begin{array}{l}\text { Rata- } \\
\text { Rata }\end{array}$} & \multirow[b]{2}{*}{ Kategori } \\
\hline & & $\begin{array}{c}\text { Tatap } \\
\text { muka } 1\end{array}$ & $\begin{array}{c}\text { Tatap } \\
\text { muka } 2\end{array}$ & $\begin{array}{c}\text { Tatap } \\
\text { muka } 3\end{array}$ & & \\
\hline 5 & Bertanggung Jawab & 88 & 88 & 88 & 88 & Baik Sekal \\
\hline 6 & Peduli Lingkungan & 86 & 86 & 94 & 88.7 & Baik Sekal \\
\hline 7 & Kerja Sama & 88 & 86 & 91 & 88.3 & Baik Sekal \\
\hline 8 & Percaya Diri & 86 & 88 & 88 & 87.3 & Baik Sekal \\
\hline 9 & Disiplin & 88 & 91 & 87 & 88.7 & Baik Sekal \\
\hline 10 & Mengelola Informasi & 88 & 88 & 91 & 89 & Baik Sekal \\
\hline
\end{tabular}

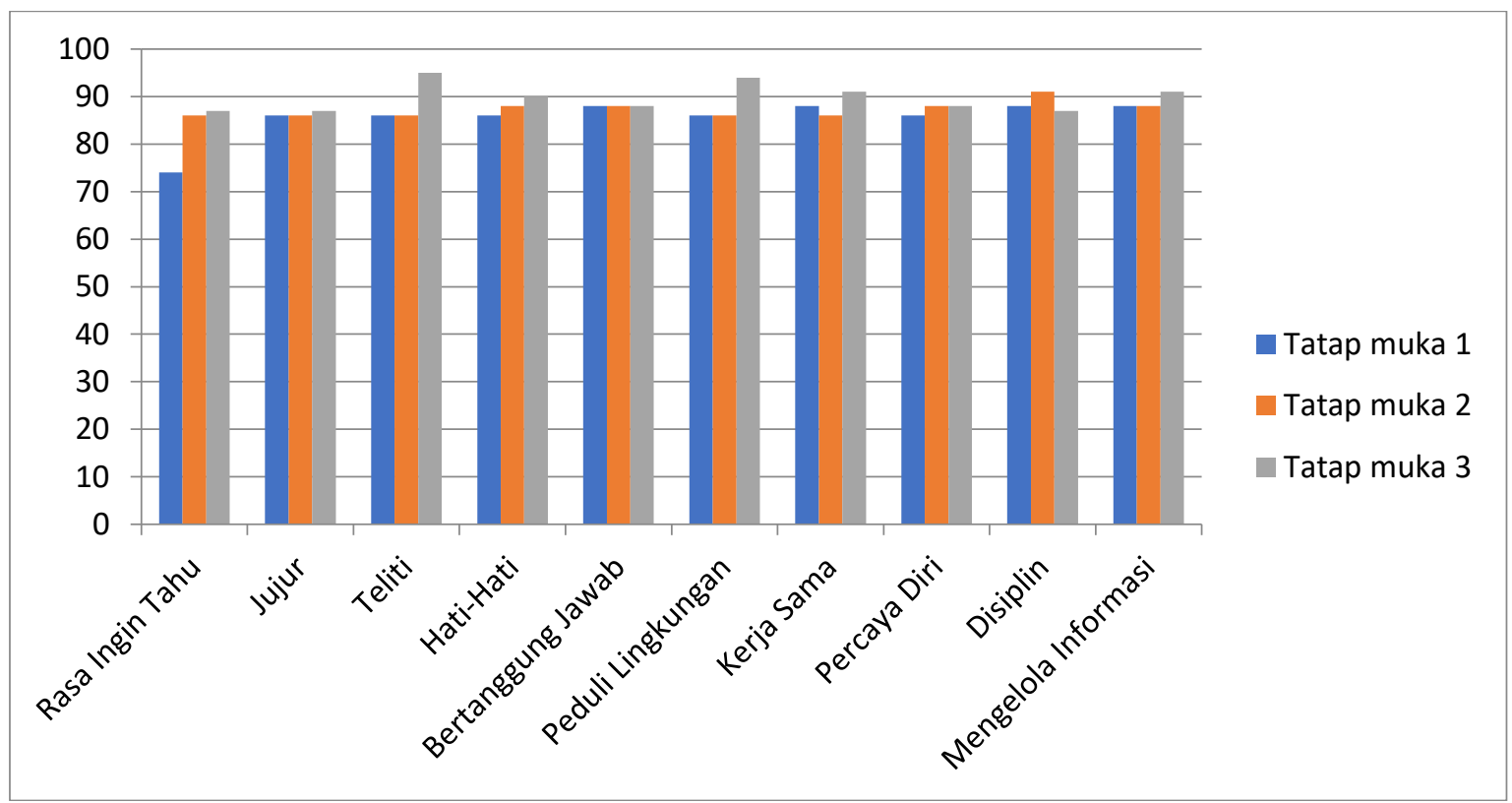

Gambar C.2

Analisa Perkembangan Scientific Attitude Peserta didik di Kelas A.

Pada gambar 3 di atas menyebutkan adanya perkembangan scientific attitude peserta didik di kelas A, yang meliputi 10 indikator yang signifikan. Scientific attitude peserta didik pada rekapitulasi hasil tatap muka kesatu sampai ketiga menujukkan scientific attitude memiliki indikator rasa ingin tahu kategori baik (di atas 70) dan 9 indikator lainnya kategori baik sekali (di atas 80). Fenomena ini membuktikan model pembelajaran IPA dengan penerapan guided inquiry learning model dapat meningkatkan scientific attitude peserta didik.

Hasil penelitian menunjukkan prosentase nilai rata-rata scientific attitude peserta didik di kelas A lebih baik daripada kelas C. Fenomena dapat diketahui dari prosentase nilai rata-rata scientific attitude peserta didik di kelas A dengan prosentase $87,6 \%$ dan di kelas $C$ dengan prosentase 56,6 \%. Adapun selisih nilai scientific attitude di kelas A dan kelas $\mathrm{C}$ dengan prosentase $31 \%$. Fenomena ini menjadi bukti adanya perbedaan scientific attitude peserta didik antara kelas A dan kelas C. Adapun perlakuan pada kelas A dengan menggunakan guided inquiry berhasil dalam mempertingkatkan scientific attitude peserta didik pada pembelajaran IPA atau sains di kelas. Hasil uji hipotesis 
scientific attitude peserta didik di kelas A dan kelas C adalah Sig. 0,000 $\leq 0,05$. Maka terdapat pengaruh yang signifikan dalam penerapan guided inquiry learning model dalam mempertingkatkan scientific attitude peserta didik pada pembelajaran IPA atau sains di kelas V, sedangkan besarnya efektivitas guided inquiry learning model untuk mempertingkatkan scientific attitude peserta didik pada pembelajaran sains di kelas memiliki uji effect cohen's 1,8 ini termasuk kategori tinggi. Faktor yang dominan mempengaruhi sikap ilmiah peserta didik adalah model pembelajaran inkuiri terbimbing memperhatikan tahapan proses aktivitas peserta didik dalam melakukan setiap petunjuk dan arahan guru sehingga peserta didik terlibat langsung dalam kegiatan ilmiah yang dapat menumbuhkan percaya diri, cinta pada literasi ilmiah yang logis, dan keingintahuan yang tinggi peserta didik dalam mencari ilmu pengetahuan secara empiris dan logis.

Fenomena ini sama dengan riset Udiani (2017:3) yang menyebutkan guided inquiry learning dapat meningkatkan ouput dan outcome belajar dan skill science process serta memunculkan scientific attitude peserta didik pada pembelajaran IPA meningkat. Dalam riset Lestari (2015: 277) menyebutkan dominasi aspek attitude dalam output dan outcome belajar IPA atau sains berupa keingintahuan peserta didik, luwes, teliti dan memiliki sikap logis yang merupakan wujud nyata dari scientific attitude. Selain itu, dengan adanya korelasi mutualistik antara pelibatan peserta didik secara aktif dengan memunculkan skill critical thinking dalam mengkonstruk dan mencari ilmu pengetahuan untuk menyelesaikan permasalahan empiris dengan scientific attitude, sehingga guided inquiry learning model mampu memunculkan scientific attitude peserta didik pada pembelajaran IPA atau sains. Dalam penelitian lain juga menyebutkan komponen riset menjadi bagian penting dalam mewujudkan peserta didik untuk melek literasi ilmiah.

Pelibatan dalam komponen riset pada setiap tatap muka pembelajaran di kelas juga dapat membentuk dalam critical thinking, percaya diri, dan cinta literasi sains sehingga dapat menjadikan peserta didik seperti layaknya seorang ilmuan (Chen, dkk., 2016: 179). Dalam riset Sayekti (2012: 147) menyebutkan pembelajaran IPA atau sains melalui penerapan guided inquiry learning model di kelas dapat memberikan peluang kemandirian peserta didik berupa pemaparan objek dan kejadian yang dikaji, membuat pertanyaan, menjelaskan fenomena alam, menguji dengan berbagai cara dan memberikan penjelasan kepada orang lain. Dengan melakukan percobaan dan eksperimen, maka peserta didik terlatih untuk meningkatkan sikap ilmiah.

\section{Efektivitas Guided Inquiry Learning Model dalam Meningkatkan Skill Critical Thinking pada Pembelajaran}

Indikator skill critical thinking peserta didik dari riset ini meliputi empat indikator, yaitu interpretation, analyses, giving conclusion, dan providing, explanation. Data diperoleh melalui soal uraian dengan 5 item soal. Soal uraian dibuat untuk mengetahui skill critical thinking peserta didik dari materi yang berbeda pada setiap tatap muka diberikan tugasan 1 sampai tugasan 3. Sedangkan untuk mengetahui analisa tentang efektifitas guided inquiry learning model dalam peningkatan skill critical thinking disebar pretest dan posttest, baik di kelas A maupun di kelas C. Adapun perkembangan skill critical thinking dengan melihat nilai tugasan satu sampai tugasan tiga peserta didik dengan dengan gambar C.3 berikut. 


\section{MADRASAH}

Jurnal Pendidikan dan Pembelajaran Dasar

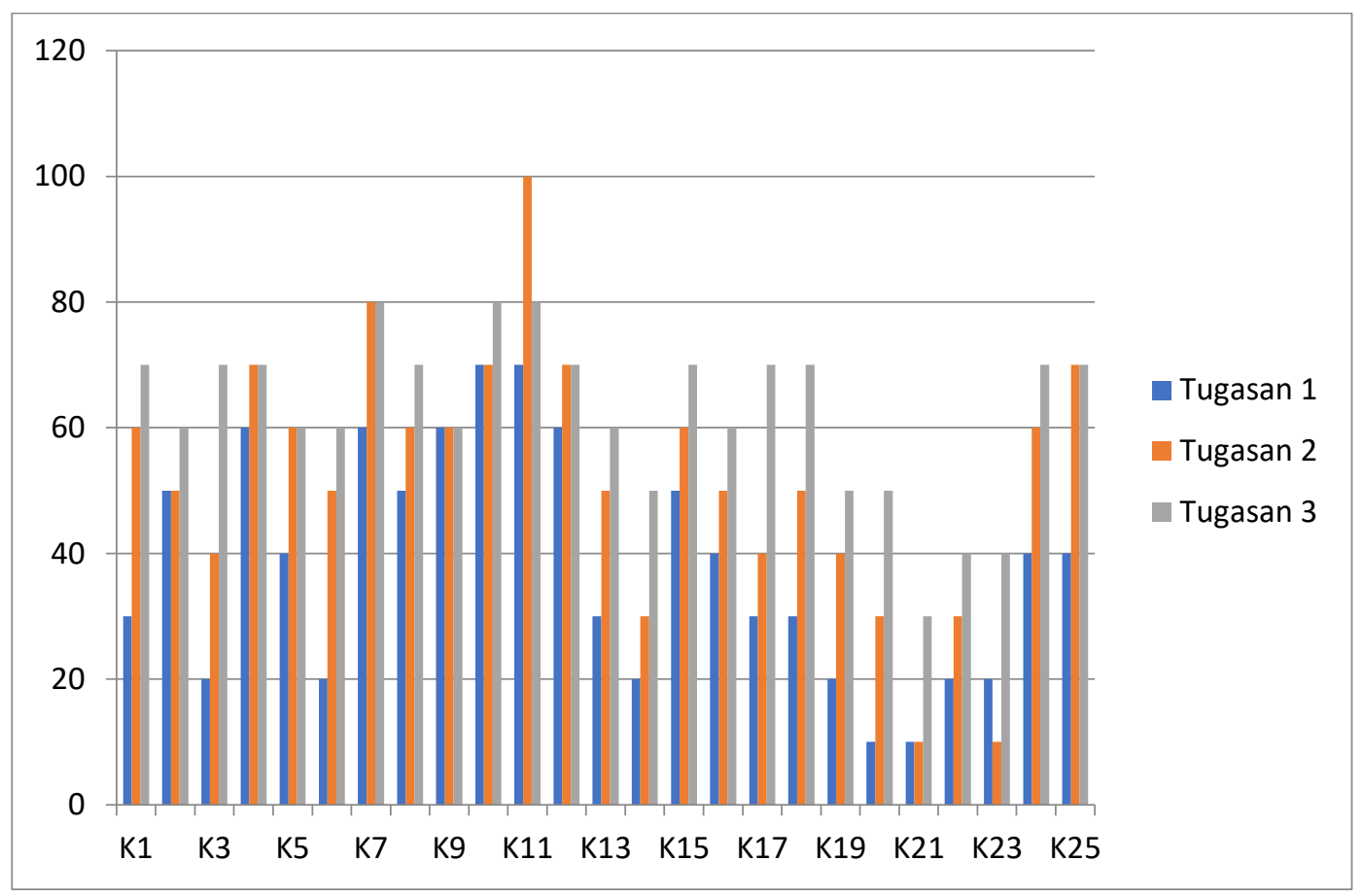

Gambar C.3

Analisa Peningkatan Nilai Tugasan 1-3 di Kelas C.

Pada gambar C.3 di atas menyebutkan adanya peningkatan nilai dari tugasan 1 hingga tugasan 3 di kelas C. Peningkatan nilai tampak pada K11 dalam skill critical thinking peserta didik namun belum mencapai maksimal. Fenomena ini terjadi dengan adanya upaya peserta didik dalam mencapai KKM 70 sebanyak $75 \%$. Analisa perkembangan nilai skill critical thinking peserta didik di kelas A dapat ditunjukkan oleh gambar C.4 sebagai berikut.

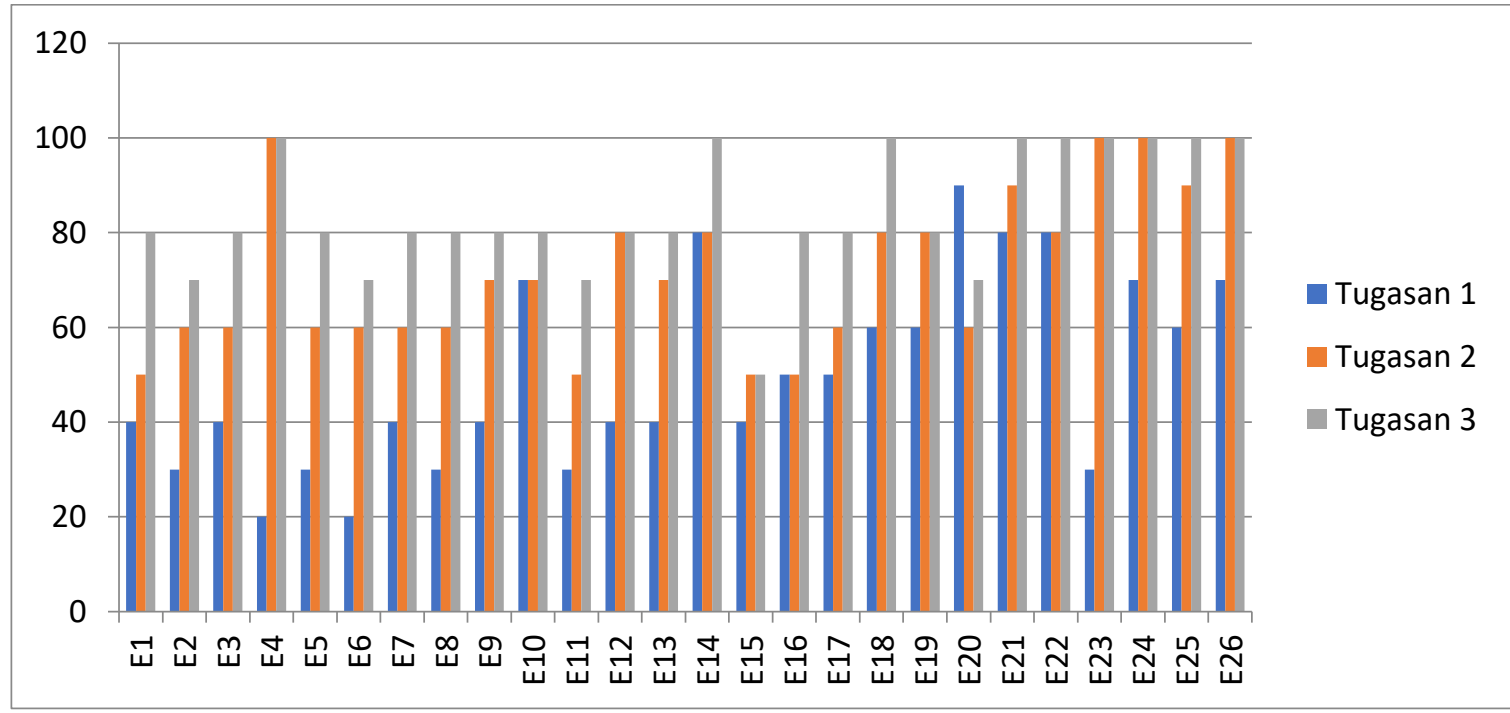

Gambar C.4

Analisa Perkembangan Nilai Tugasan 1-3 di Kelas A. 
Pada gambar C.4 di atas menyebutkan analisa perkembangan nilai peserta didik dalam tugasan 1-3 di kelas A dengan adanya peningkatan skill critical thinking peserta didik menjadi baik. Hal ini dikarenakan peserta didik sudah mencapai ketuntasan belajar dan klasikan telah mencapai lebih 75\% yang sesuai dengan nilai KKM 70. Riset ini juga menunjukkan perbedaan antara kelas eksperimen dan kelas control dalam penerapan inquiry learning model dan skill critical thinking student di kelas. Nilai rata-rata pretest di kelas eksperimen sebesar 38,84 dan nilai rata-rata posttest sebesar 84,53 . Sedangkan di kelas eksperimen nilai rata-rata pretest sebesar 33,16 dan nilai rata-rata posttest sebesar 48,85 . Oleh karena itu, dapat dianalisis bahwa nilai rata-rata di kelas eksperimen lebih besar dibandingkan dengan nilai rata-rata di kelas kontrol. Adapun uji hipotesis menunjukkan riset ini memiliki korelasi pengaruh antara inquiry learning model dan skill critical thinking student pada pembelajaran IPA. Fenomena ini terjadi karena guru selalu melakukan kegiatan pembelajaran dengan memperhatikan tahapan-tahapan dalam model pembelajaran inkuiri terbimbing.

Riset ini sejalan dengan riset Kuhlthau (2010:19) dalam menyebutkan adanya peningkatan skill critical thinking student pada inqury learning model. Begitu pula dengan riset Sutisna (2017: 27) yang menyebutkan adanya korelasi pengaruh antara inquiry learning model dan skill critical thinking serta understanding of concept dari peserta didik. Selain itu, penelitian Nurliana (2017: 56) yang menyebutkan adanya korelasi peningkatan skill of critical thinking student dan development of LKS based inquiry, dalam kefektifan dan kepraktisannya. Falahudin (2016: 85) menyebutkan ada korelasi inquiry model terhadap skill of critical thingking student. Dalam riset Rachmawati (2016: 42) menyatakan skill critical thinking student dan understanding of science concept dalam pembelajaran. Sejalan dengan penelitian Kristanto (2015: 197) yang menyatakan adanya pengaruh inqury learning model dengan critical thinking student.

\section{KESIMPULAN}

Berdasarkan pemaparan di atas, dapat ditarik simpulan sebagai berikut:

1. Terdapat efektifitas dalam pembelajaran model inquiry terbimbing.

2. Terdapat efektivitas dan peningkatan setelah penggunaan model pembelajaran melalui pendekatan inkuiri terbimbing terhadap sikap ilmiah peserta didik dan keterampilan berfikir kritis peserta didik.

\section{REFERENSI}

Abdullah Ridwan Sani. 2014. Pembelajaran Saintifik untuk Implementasi Kurikulum 2013. Jakarta: Bumi Aksara.

Alandeom W. Oliveira. 2010. Developing Elementary Teachers' Understanding Of The Discourse Structure Of Inquiry-Based Science Classrooms, International Journal of Science and Mathematics Education 8, no. 2. April 1.

Atang Sutisna. 2017. Pengaruh Model Pembelajaran Guided Inquiry dan Guided Discovery terhadap Kemampuan Berpikir Kritis dan Pemahaman Konsep pada Pembelajaran TematikIntegratif di Kelas V SDN 2 Padokan Bantul Yogyakarta. Tesis Universitas Negeri Yogyakarta. 


\section{MADRASAH}

Jurnal Pendidikan dan Pembelajaran Dasar

p ISSN: 1979-5599 | e ISSN: 2502-194X

Carol C Kuhlthau. 2010. Guided Inquiry; School Library in the 21st century. Journal School

Of Communication, Rutgers The State University Of New Jersey, USA Volume 16 Number 1.

Handayani, B.T., Arifuddin, M., \& Misbah. 2017. Meningkatkan Keterampilan Proses Sains Melalui Model Guided Discovery Learning. Jurnal Ilmiah Pendidikan Fisika, 1(3), 143-154.

Irham Falahudin, dkk. 2016. "Pengaruh Model Pembelajaran Inkuiri Terbimbing terhadap Kemampuan Berpikir Kritis Peserta didik pada Pembelajaran Materi Pengelolaan Lingkungan di SMP Negeri 2 Tanjung Lago Kabupaten Banyuasin", Jurnal Bioilmi Vol, 2 No, 2, FTIK UIN Raden Fatah Palembang.

Jean Piaget dan Barbel Inhelder. 2010. The Psychology of The Child, diterjemahkan oleh Miftahul Jannah. Yogyakarta: Pustaka Pelajar.

Lestari, Inayatul Lailil. 2015. Meningkatkan kemampuan berpikir kritis dan sikap ilmiah peserta didik melalui perpaduan metode inquiry dan reciprocal teaching pada materi sistem ekskresi di kelas XI IPA 5 SMA Negeri 7 Kediri Tahun Pelajaran 20142015, Seminar Nasional XII Pendidikan Biologi, FKIP UNS.

Michael J. Prince and Richard M. Felder. 2006. Inductive Teaching and Learning Methods; Definition, Comparisons, and Research Bases, Bucknell University. Journal Engr. Education 95 (2).

National Research Council. 2011. Inkuiri dan Standar-Standar Pendidikan Sains Nasional Sebuah Panduan untuk Pengajaran dan Pembelajaran, Washington DC: National Academy Press.

Ni Ketut Udiani, Putu Aryana dan Marhaeni. 2017. Pengaruh Model Pembelajaran Inkuiri Terbimbing terhadap Hasil Belajar IPA dengan mengendalikan Keterampilan Proses Sains Peserta didik Kelas IV SD N0.7 Benoa Kecamatan Kuta Selatan Kabupaten Badung, Journal Pascasarjana Universitas Pendidikan Ganesha, Vol 7 No 1.

Nur. 2008. Pemotivasian Peserta didik untuk Belajar. Surabaya: Pusat Sains dan Matematika Sekolah Press.

Nurliana. 2017. Pengembangan LKS Berbasis Inkuiri Terbimbing pada Materi Tekanan Untuk Meningkatkan Keterampilan Berfikir Kritis Peserta didik, Tesis Pendidikan IPA, Program Pascasarjana Universitas Bandar Lampung.

Puspita, A.R., Paidi, \& Nurcahyo, H. 2017. Analisis Keterampilan Proses Sains LKPD Sel di SMA Negeri Kota Bekasi. Jurnal Prodi Pendidikan Biologi, 6(3), 164-170.

Saidaturrahmi, Abdul Gani, Muhammad Hasan. 2019. Penerapan lembar kerja peserta didik inkuiri terbimbing terhadap keterampilan proses sains peserta didik. Jurnal Pendidikan Sains Indonesia (Indonesian Journal of Science Education), 7(1):01-08.

Sularso, Widha Sunarno, Sarwanto. 2017. Understanding students' concepts through guided inquiry learning and free modified inquiry on static fluid material. International Journal of Science and Applied Science, 2 (1): 01-05.

Sayekti, Sarmanto dan Suparni. 2012. Pembelajaran IPA Menggunakan Inkuiri Terbimbing Melalui Metode Eksperimen dan Demonstrasi Ditinjau dari Kemampuan Analisis dan Sikap Ilmiah Peserta didik, Jurnal Inkuiri Pascasarjana UNS. 
Sudarisman. 2012. Implementasi Model Guided Inquiry dengan Variasi Teknik pada Pembelajaran Biologi di SMA. Prosiding Seminar Nasional MIPA dan Pembelajaran, Malang, 13 Oktober 2012 ISBN 978-602-97895-6-0.

Sukamdinata, Nana Syaodih. 2012. Metode Penelitian Pendidikan. Bandung: Roesdakarya, cet. 8 .

Varicha Ulva, Ibrohim and Sutopo. 2017. "Mengembangkan Sikap Ilmiah Peserta didik SMP Melalui Pembelajaran Inkuiri Terbimbing Pada Materi Ekosistem," Universitas Negeri Malang Jurnal Pendidikan: Teori, Penelitian, dan Pengembangan 2, (5): 622-26.

Waode Rachmawati. 2016. “Penerapan Metakognisi pada Model Inkuiri Terbimbing dalam Meningkatkan Keterampilan Berfikir Kritis dan Pemahaman Konsep Biologi pada Peserta didik SM",. Tesis Pendidikan IPA, Program Pascasarjana Universitas Halu Oleo, Kendari.

William J. Newman et al.. 2004. “Dilemmas of Teaching Inquiry in Elementary Science Methods," Journal of Science Teacher Education 15, no. 4, November 1.

Ying-Chih Chen, Brian Hand, and Soonhye Park. 2016. "Examining Elementary Students' Development of Oral and Written Argumentation Practices Through ArgumentBased Inquiry," Science \& Education 25, no. 3-4, May 1. 